\title{
Humic Substances and Efficient Microorganisms: Elicitation of Medicinal Plants-A Review
}

\author{
M. M. A. Pereira ${ }^{1}$, L. C. Morais ${ }^{1}$, E. A. Marques ${ }^{1}$, A. D. Martins ${ }^{1}$, V. P. Cavalcanti ${ }^{1}$, F. A. Rodrigues ${ }^{1}$, \\ W. M. Gonçalves ${ }^{1}$, A. F. Blank ${ }^{2}$, M. Pasqual ${ }^{1} \&$ J. Dória ${ }^{1}$ \\ ${ }^{1}$ Department of Agriculture, Federal University of Lavras, Brazil \\ ${ }^{2}$ Department of Agriculture, Federal University of Sergipe, Brazil \\ Correspondence: M. M. A. Pereira, Department of Agriculture, Federal University of Lavras, Brazil. Tel: \\ 55-991-004-598. E-mail: agro.maysa@gmail.com
}

Received: January 23, 2019

Accepted: April 2, 2019 Online Published: May 31, 2019

doi:10.5539/jas.v11n 7 p268

URL: https://doi.org/10.5539/jas.v11n7p268

\begin{abstract}
In function of the green revolution the indiscriminate use of agrochemicals and pesticides in agriculture has been also shown in the production of medicinal plants, resulting in the increase of productivity but with high residual contamination and low rates in the production of secondary metabolites responsible for the biological and pharmacological activity in vegetable drugs. In another hand, new techniques of elicitation has been applied to stimulate the medicinal plants production through the organic and agroecological management, contributing for the increase of performance, quality and production. In this context, it is aimed with this review to present such as the humic substances: fulvic acid, humic acid and efficient microorganisms which influence and help the ontogeny and the secondary metabolites production of medicinal plants. The reviewed articles show that the use of fulvic acid, humic acid and efficient microorganisms in the production of medicinal plants contributes on the increase of biosynthesis, secondary metabolites production such as coumarins, alkaloids, phenylpropanoids and essential oils, as well as the increase of nutrients absorption, growth and development of species.
\end{abstract}

Keywords: biostimulation, essential oils, secondary metabolism, in vivo, humic acid

\section{Introduction}

Since the beginning of the green revolution the agriculture panoram has changed by the excessive use of fertilizers, pesticides, land mechanization and latifundia concentration (Lazzari \& Souza, 2017; Matos \& Pessoa, 2011). In order to increase productivity these agrochemicals has been indiscriminately used not only in grains and horticultural crops, but also in medicinal plants (Pereira \& Raimunda, 2016).

The medicinal plants are essential source of secondary metabolites and bioactive compounds responsible for the biological and pharmacological activity of the plant in vivo (Costa \& Jorge, 2011; Czelusniak, Brocco, Pereira, \& Freitas, 2012; Pereira \& Cardoso, 2012; Gobbo-Neto \& Lopes, 2007), as alkaloids, phenolic compounds, terpenes and others. Historically they have been used by the population through homemade crops, live pharmacies, as well as acquisition in natural products stores and industrial herbal medicines (Calixto \& Siqueira, 2008).

In Brazil, the cultivation of medicinal species must be totally pesticide free. However, residues of undesirable and undeclared substances such as pesticides, radioactive compounds, pathogens, mycotoxins, heavy metals and arsenic are constantly found in plant-derived drugs and phytotherapics altering the quality of the products with therapeutic purposes in the treatment of various diseases (Brasil, 2014).

Research on the cultivation of species with therapeutic purposes is still recent. Therefore, some technologies used in the production of large crops and vegetables, such as the use of elicitors (endogenous or exogenous molecules) in vivo (Canellas et al., 2015), can be applied in the organic cultivation of medicinal plants. Since research with the use of elicitor agents has been focused more in in vitro culture (Rafiee et al., 2016).

Studies carried out with plants under field grown highlights the use of plant growth promoting fungi (PGPF), plant growth promoting rhizobacterium (PGPR) (Adesemoye et al., 2009; Bhattacharyya et al., 2012), humic substances (fulvic and humic acids) (Canellas et al., 2014; Olivares et al., 2017), seaweed extracts (Craigie, 
2011), hydrolyzed proteins and amino acids (Calvo et al., 2014). These bioestimulants can influence on ontogeny, secondary metabolite biosynthesis, efficiency and nutrient uptake by plants.

Researches have been done about the effect of bioestimulants such as microorganisms, rhizobacterium and humic substances on the production of medicinal plants in vitro (Halpern et al., 2015; Canellas et al., 2015; Olivares, 2017). Therefore, it is necessary to know if the content of secondary metabolites changes when the elicitor agents are applied in vivo and if its application in agroecological systems are economically and socially viable, overcoming the conventional agriculture and keeping the levels of productivity.

On this review, we show studies about the use of humic substances and microorganisms applied in the field (in vivo), their effect on ontogeny and on metabolites content in medicinal plants. The numbers of studies in vivo are extremely low, which makes it a scientific and social challenge for the advancement of agroecology and organic production of medicinal plants.

\section{Humic Substances: Humic Acid and Fulvic Acid}

The biological structure of the soil is rich in microorganisms that perform essential role in the carbon cycle and in the genesys of humic substances (Bakker et al., 2013; Fischer et al., 2017). Amongst the exudades released by the microorganisms present in plants, we can mention the formic organic acids, acetic, oxalic, tartaric and citric (Canellas et al., 2008; Zhalnina et al., 2018; Licá et al., 2018), the protons dissociate-helpers in the decomposition of minerals in soil in which middle life is too short, as well as the aromatic acids, benzene-carboxylic and phenolics (M. A. Baldotto \& E. B. Baldotto, 2014).

The organic material is decomposed into new material (humus) through the microorganisms and chemical degradation of the biota constituting the biomolecules which are placed between the horizons $\mathrm{O}$ and $\mathrm{A}$ (Ebeling et al., 2011). The humic substances are organic compounds condensated that differ from biopolymers by its molecular structure and high soil persistence (Nebbioso \& Piccolo, 2012). According to the International Humic Substances Society, the humic substances can be defined by macromolecules or supramolecules (Fischer, 2017).

The humic substances contain a hydrophilic portion and other one- hydrophobic (Canellas et al., 2008; Fischer, 2017) where the humic acid (HA) is founded turned to the inside part and a hydrophilic fulvic acid turned to the outside (Nebbioso \& Piccolo, 2012; Drosos, 2017). These aggregate supramolecules are organised in high and low weight of organic compounds (Kawahigashi, 2005) and has varying specified structure features accordingly with the organic matter and time of transformation (Asli, 2010; Nebbioso \& Piccolo, 2012).

The humic acids influence on the fruits, flowers and seeds development (M. A. Baldotto \& E. B. Baldotto, 2015) that acts in several phases of the vegetable physiology (Canellas \& Olivares, 2014) such as growth, development, photosynthetic structures of respiratory activity (Costa et al., 2008); changes on biochemical pathways as primary and secondary metabolism (Trevisan et al., 2011; Aminifard et al., 2012; Canellas \& Olivares, 2014; Nardi et al., 2017). Due to all these beneficial effects of elicitors on plant productivity, they have attracted the interest of farmers and companies.

Researches show that humic substances contribute on the better absorption of nutrients (Halpern et al., 2015). They also perform indirect actions over the chemical and dynamic of the microorganism on the rhizosphere, altering the interaction soil-plant-microbiota (Canellas \& Olivares, 2014) in relation to the assimilation of macro and micro nutrients as a function of the increase on the permeability of the plasmatic membrane with the action of the humic substances (Silva Lima et al., 2014).

Changes on the uptake of nutrients and humic substances related to the absorption rates are explained by the kinetic parameters of absorption, which are estimated through the maximum absorption rate, ion concentration and minimum ion concentration in the solution taht the plant cannot absorb (Silva Lima et al., 2014).

Therefore, the humic and the fulvic acid can influence directly and indirectly in the plants metabolism (Canellas et al., 2014; Vaccaro et al., 2015), altering the metal complexation, increasing the capacity of cationic exchange (Ateia et al., 2017; Lee et al., 2017; Kwiatkowska-Malina, 2018), nutrients supply and humidity retention, interfering on the ions transportation, respiratory activity, chlorophyll levels, nucleic acid synthesis and on the activity of several enzymes (Muscolo et al., 2013; Ozfidan-Konakci et al., 2018; Shahabivand et al., 2018). 
Table 1. Overview of the medicinal plants species elicited by humic substances: fulvic and humic acid

\begin{tabular}{|c|c|c|c|c|c|c|}
\hline Scientific name & Application via & Evaluation & Pharmacogenic & Efficient Treatment & Results & Articles \\
\hline $\begin{array}{l}\text { Justicia pectoralis } \\
\text { Jacq. }\end{array}$ & Pulverization & Coumarin & $\begin{array}{l}\text { Leaf and } \\
\text { dry stem }\end{array}$ & $\begin{array}{l}\text { Humic Acid } \\
\text { dinamization } \mathrm{CH}_{3}\end{array}$ & $\begin{array}{l}\text { Dinamizations } \\
>\text { Coumarin rates on } \\
\text { plants of } 54.35 \%\end{array}$ & $\begin{array}{l}\text { Andrade et al. } \\
\text { (2001) }\end{array}$ \\
\hline Lantana camara $L$. & Soil & Growth and development & - & - & $\begin{array}{l}>\text { Vegetative period } \\
\text { and growth } \\
>\text { Organogenesis }\end{array}$ & $\begin{array}{l}\text { Costa et al. } \\
(2008)\end{array}$ \\
\hline $\begin{array}{l}\text { Hibicus } \\
\text { sabdariffa } \mathrm{L} .\end{array}$ & $\begin{array}{l}\text { Leaf } \\
\text { pulverization }\end{array}$ & $\begin{array}{l}\text { Antioxidant activity, } \\
\text { anthociocyns rates }\end{array}$ & Whole plant & - & $\begin{array}{l}>88.0 \& 89.33 \% \\
\text { anthocyanins and } \\
\text { antioxidants } \\
>\text { Effciency in the } \\
\text { absorption of } \mathrm{N} \text { and } \mathrm{P}\end{array}$ & $\begin{array}{l}\text { Ahmed et al. } \\
\text { (2011) }\end{array}$ \\
\hline $\begin{array}{l}\text { Hyssopus } \\
\text { officinalis } L \text {. }\end{array}$ & Soil & Non definition & Leaf & $300 \mathrm{mg} / \mathrm{L}$ & $\begin{array}{l}>\text { Biomass rates } 88 \% \\
>\text { Essential oil rates } 71 \%\end{array}$ & $\begin{array}{l}\text { Khazaie et al. } \\
\text { (2011) }\end{array}$ \\
\hline $\begin{array}{l}\text { Chrysanthemum } \\
\text { indicum } \mathrm{L} \text {. }\end{array}$ & $\begin{array}{l}\text { Leaf } \\
\text { pulverization }\end{array}$ & $\begin{array}{l}\text { Total Carbohydrates, } \\
\text { proline concentration }\end{array}$ & Fresh plant & $\begin{array}{l}1.0,1.5 \text { and } 2.0 \% \\
\text { Humic Acid }\end{array}$ & $\begin{array}{l}>\text { Total carbohydrates, } \\
\text { chlorosis improvement } \\
<\text { Proline rates }\end{array}$ & $\begin{array}{l}\text { Mazhar et al. } \\
\text { (2012) }\end{array}$ \\
\hline $\begin{array}{l}\text { Capsicum annum } \\
\text { var. Red chili }\end{array}$ & soil & $\begin{array}{l}\text { Antioxidant, total } \\
\text { phenols, flavonoids, content } \\
\text { of capsaicin, lycopene } \\
\text { and B-Carotene }\end{array}$ & Fruits & $100 \mathrm{mg} \mathrm{kg}^{-1}$ & $\begin{array}{l}\text { > Antioxidants, flavonoids, } \\
\text { capsaicine, carotenoids } \\
\text { < Total phenols }\end{array}$ & $\begin{array}{l}\text { Aminifard } \\
\text { et al. (2012) }\end{array}$ \\
\hline Rhodiola rosea $\mathrm{L}$. & soil & $\begin{array}{l}\text { Enzymatic acitivity } \\
\text { and phenillpropanoids }\end{array}$ & $\begin{array}{l}\text { Rhizome } \\
\text { and roots }\end{array}$ & $\begin{array}{l}\text { Leonardite } 95.5 \% \\
\text { Humic Acid \& } \\
4 \% \text { fulvic acid }\end{array}$ & > Phenylpropanoids rates & $\begin{array}{l}\text { Kołodziej } \\
\text { et al. (2013) }\end{array}$ \\
\hline Mentha piperita $L$. & $\begin{array}{l}\text { Leaf } \\
\text { pulveization }\end{array}$ & $\begin{array}{l}\text { Cineol, menthol, } \\
\text { mentone, isomentone }\end{array}$ & leaves & $0.4 \mathrm{~g} \mathrm{~L}^{-1}$ Humic Acid & $\begin{array}{l}>\text { Menthol essential oil } \\
\text { rates from } 48 \% \text { to } 57.5 \% \text {, }\end{array}$ & $\begin{array}{l}\text { El-Gohary } \\
\text { et al. (2014) }\end{array}$ \\
\hline Allium sativum $L$. & Fertirrigation & $\begin{array}{l}\text { Total phenols, } \\
\text { flavonoids, allicin }\end{array}$ & Whole plant & $20 \mathrm{~kg} \mathrm{ha}^{-1}$ & $\begin{array}{l}>\text { Total phenols } \\
\text { and flavonoids } \\
>\text { Antioxidant activity }\end{array}$ & $\begin{array}{l}\text { Ghasemi } \\
\text { et al. (2015) }\end{array}$ \\
\hline $\begin{array}{l}\text { Mintha piperita } \\
\text { var. Citrata }\end{array}$ & $\begin{array}{l}\text { Leaf } \\
\text { pulverization }\end{array}$ & $\begin{array}{l}\text { Essential Oil (Linalool, } \\
\text { linalyl acetate, caryophyllene, } \\
\text { b-fenchilíco) }\end{array}$ & Fresh leaf & $\begin{array}{l}0.4 \mathrm{~g} \mathrm{~L}^{-1} \\
\text { Humic Acid }\end{array}$ & $\begin{array}{l}>\text { Essential oil rates } \\
>12.49 \% \text { to } 25.23 \% \\
\left(1^{\circ} \text { cut }\right) \text { and } 26.37 \% \\
\left(2^{\circ} \text { cut }\right) \text { Linalool }\end{array}$ & $\begin{array}{l}\text { Hendawy } \\
\text { et al. (2015) }\end{array}$ \\
\hline $\begin{array}{l}\text { Calendula } \\
\text { officinalis } L \text {. }\end{array}$ & Leaf spray & $\begin{array}{l}\text { chlorophyll (A \& B), } \\
\text { carotenoids }\end{array}$ & Flower & $\begin{array}{l}\text { Bovine manure, } \\
\text { ascorbic acid } 100 \\
\text { ppm and humic } \\
\text { acid in } 100 \mathrm{ppm}\end{array}$ & $\begin{array}{l}>\text { Fresh and dry weight of } \\
\text { sprouts, roots and } \\
\text { inflorescence by plant }(\mathrm{g}) \\
>\text { Chlorophyll (A \& B), } \\
\text { total carotenoids in } \\
\text { leaves and flowers }\end{array}$ & $\begin{array}{l}\text { Mohsen } \\
\text { et al. (2016) }\end{array}$ \\
\hline $\begin{array}{l}\text { Gerbera planta } \\
\text { cv. Malibu }\end{array}$ & soil & $\begin{array}{l}\text { Antioxidant acititity, } \\
\text { malondialdehyde }\end{array}$ & Flowers & $\begin{array}{l}\text { Humic Acid } \\
500 \mathrm{mg}\end{array}$ & $\begin{array}{l}>\text { Malondialdehyde rates } \\
>\text { Superoxide dismutase } \\
\text { activity }\end{array}$ & $\begin{array}{l}\text { Haghighi } \\
\text { et al. (2016) }\end{array}$ \\
\hline $\begin{array}{l}\text { Anethum } \\
\text { graveolens L. }\end{array}$ & $\begin{array}{l}\text { Leaf } \\
\text { pulverization }\end{array}$ & $\begin{array}{l}\text { Essential oil (carvone, } \\
\text { dihidrocarvone, limonene, } \\
\text { dill apiol e piperitone) }\end{array}$ & $\begin{array}{l}\text { Anethum straws } \\
\text { and seed }\end{array}$ & $\begin{array}{l}400 \mathrm{ppm} \text { humic } \\
\text { acid and } 400 \mathrm{ppm} \\
\text { dactic indol acid }\end{array}$ & $\begin{array}{l}>\text { Oil rates in the straw } \\
\text { (limolene and carvone) } \\
>\text { Oil rates in the seeds }\end{array}$ & $\begin{array}{l}\text { Said-Al } \\
\text { et al. (2016) }\end{array}$ \\
\hline
\end{tabular}

\section{The Influence of Humic Substances on the Ontogeny, Primary and Secondary Metabolism}

Studies evaluating the application of humic substances in medicinal plants in vivo (Table 1) demonstrate that those substances can contribute to the increase of the biosynthesis of secondary metabolites and to the activity of bioactive substances from different classes, such as flavonoids, coumarins, phenylpropanoids, total phenols and anthocyanins (Ahmed et al., 2011; Khazaie et al., 2011; Aminifard et al., 2012; El-Gohary et al., 2014; Ghasemi et al., 2015; Hendawy et al., 2015; Said-Al et al., 2016).

There are different ways of applying humic substances: via soil, spray or fertigation (Kołodziej et al., 2013; Hendawy et al., 2015; Ghasemi et al., 2015). Nevertheless, those substances significantly increased the biosynthesis of the metabolism of medicinal plants and production of metabolites with biological and 
pharmacological properties independent of the way they were applied on the plants (Andrade et al., 2001; Khazaie et al., 2011; Kołodziej et al., 2013).

Humic acid can also be applied via homeopathy techniques promoting a $55.10 \%$ increase in coumarin content in Justicia pectoralis Jacq. (Andrade et al., 2001) when dynamized as well as demonstrated great variability in the electromagnetic field of these plants.

Although the application procedure does not show difference on the performance and biosynthesis of metabolites on medicial species, humic substances applied via soil act as soil conditioners. They interact with great number of functional groups which allows wide espectro of reactivity with other molecules (Drosos et al., 2017), hydrophilicity forming hydrogen bonds with water and the structural malleability wich is the capacity of intermolecular association and changes on $\mathrm{pH}$ and redox values (Caron et al., 2015; Fischer, 2017).

These changes in the physical, chemical and microbiological structure of the soil have the purpose of greater water retention, aeration, directly influencing root growth, nutrient absorption, primary and secondary metabolic pathways (Canellas \& Olivares, 2014; Canellas et al., 2015; Olivares et al., 2017; Ozfidan-Konakci et al., 2018), hormone signaling and, consequently, higher yield of the medicinal plants.

In this context, the application of humic and fulvic acid in vivo increased growth, development and organogenesis of the plants in the field, influencing on the differentiation of the vegetative tissues in the production of flowers (Costa et al., 2008). Higher content and concentration of active ingredients of the essential oils of Hyssopus officinalis L., Mentha piperita L, Mintha piperita var. Citrate, Anethum graveolens L. was also observed, showing a positive corelation between the increase of dry or fresh biomass with the essential oil content (Hendawy et al., 2015; El-Gohary et al., 2014).

Anthocyanins and phenolic compounds (monoterpene, terpene, phenylpropanoids, flavonoids) are the main classes of secondary metabolites influenced by the application of humic substances found in the literature (Haghighi et al., 2016; Said-Al et al., 2016). In fruits of Capsicum annum var. Red chili humic acid increased the concentration of flavonoids, capsaicin, carotenoids (lycopene and B-carotene) and antioxidant activity (Aminifard et al., 2012).

Humic substances improves the root system development, which contributes to higher nutrient uptake efficiency, leading to changes on the root exudation profile (Canellas \& Olivares, 2014), lateral and adventitious roots formation. These responses involve mechanisms of cellular stimulation and differentiation that act as messenger inducing physiological effects, as well as influence on the production of chlorophyll A and B and carotenoid content (Ghasemi et al., 2015).

Therefore, the application of humic substances in the in vivo cultivation of medicinal plants opens up the opportunity for the development of organic fertilizers for agroecological systems, aiming at good quality raw material without pesticides with increased concentration of secondary metabolites biologically and pharmacologically interesting (Canellas et al., 2015; Halpern et al., 2015, Olivares et al., 2017).

\section{Application of Plant Growth Promoting Microorganisms}

It is estimated that living microorganisms, aggregate to organic matter and rhizosphere, occupy less than 5\% of the total space of soil. What makes this environment a dynamic and living space, with a central role in processes of decomposition and cycling of nutrients available to the plants through the mineralization (Chavarria et al., 2018; Lehmann et al., 2018; Zheng et al., 2018).

The microorganisms applied on agroecological and organic systems have influence on the health and microbial activity of the soil (Chavarria et al., 2018). Soil community is diverse, constituted by fungi and bacterium that perform as promoters of plant growth (Leite et al., 2016; Silva et al., 2017; Trinh et al., 2018). Thus the microorganisms of the rhizosphere shape efficient systems for absorption and catabolism of organic compounds existent in the exudate roots (Bakker et al., 2013; Ahemad \& Kibret, 2014).

Plant growth promoting bacterium can influence directly or indirectly the general morphology of plants, as they have the ability to colonize tissues and different mechanisms of action (Pandya et al., 2013; Chagas et al., 2018). They can act on iron sequestration and phytoremediation (Karami \& Shamsuddin, 2010), phosphorus solubilization, atmospheric nitrogen fixation (Santi et al., 2013; Ahemad \& Kibret, 2014), hormone production, organic siderophore compounds (Bhattacharyya \& Jha, 2012), systemic resistance to pathogens, tolerance to abiotic and biotic stress (Etesami \& Maheshwari, 2018; Shameer \& Prasad, 2018).

The main efficient microorganisms associated to rhizosphere capable of exerting a beneficial effect on plant growth and physiology are the Azospirillum spp., Alcaligenes spp., Artrobacter spp., Acinetobacter spp., Bacillus 
spp., Burkholderia spp., Enterobacter spp., Erwinia spp., Flavobacterium spp., Pseudomonas spp., Rhizobium spp., Serratia spp., Streptomyces spp. and mycorrhizal fungi as the Arbuscular mycorrhizal fungi present in $80 \%$ of the roots (Bulgarelli et al., 2013; Gupta et al., 2018).

Bacterium of the genus Azospirillum spp., Bacillus spp. and Enterobacter spp. are effective for promoting better performance of plants acting on the regulation of physiological process (Bhattacharyya et al., 2012), stimulating the ability of producing and degrading plant growth regulators like gibberellins, auxins, cytokinins and ethylene phytohormones (Calvo et al., 2014).

The role of microorganisms applied to agriculture are diverse, for example, mycorrhizal arbuscular fungi have the ability to solubilize phosphorum $(\mathrm{P})$ by secretion of phosphatases which degrade the $\mathrm{P}$ organic or the acids that dissolve inorganic compounds of P (Richardson et al., 2009; Yousefi et al., 2011). The free-living diazotrophic microorganisms (Azospirillum, Psudomonas and Cyanobacterium ) can fix nitrogen from the atmosphere to the soil to be mineralized and made it available to the plants in the form of ammonia they can also synthesize phytohormones (Fukami et al., 2018).

Besides, microorganisms can act as elicitors and increase the production of secondary metabolites involved in the biological and pharmaceutical activity of medicinal plants (Mohammadi et al., 2017), such as flavonoids and terpenes content, phenolic compounds, microbial activity, chlorophyll content, nutrient uptake, plant growth and development (Banchio et al., 2008; Cappellari et al., 2013; Zhao et al., 2016; Damam et al., 2016; Swamy et al., 2016).

Most of the studies regarding the use of microorganisms on medicinal plants aiming phytochemical and biochemical changes on secondary metabolites production were carried out in vitro (Rafiee et al., 2016; Du et al., 2013; Vafadar et al., 2014; Çetın et al., 2016). However, researches about the use of elicitors agents in the field are very important due to its great and innovative potential on the organic grown of medicinal plants, once uncontrolled edaphoclimatic factors may influence the colonization and the mechanisms of action of growth promoting microorganisms.

Thus, the use of efficient microorganisms as phytoremediators, bioprotectors and biofertilizers are potential tools for organic and agroecologic agriculture, improving plant physiology, intermediating the production of substances of the primary and secondary metabolism, which are related to yield, production of active ingredients and essencial oil with good quality for therapeutic use.

\section{Influence of Microrganisms on Phytochemical Composition}

Microorganisms (fungi and bacterium) applied in the cultivation of medicinal plants in vivo (Table 2) had great influence on plant growth and development, photosynthetic rate, production of secondary metabolites, abiotic stress tolerance and increased synthesis of active compounds (Aseri et al., 2008; Shahmohammadi et al., 2014; Akhazari et al., 2015; Tahami et al., 2017).

Interactions between microorganisms and medicinal plants can lead to neutral, negative or positive effects on plants (Ahemad \& Kibret, 2014). In this review, we verified the use of different genera of microorganisms such as Bacillus spp., Azotobacter spp. and Azospirillum spp., heterotrophic and nitrogen-fixing aerobic bacterium, being that Azospirillum genera (facultative endophytes) the most commonly applied on the plants (Mohammad et al., 2012; Shahmohammadi et al., 2014; Tahami et al., 2017).

Facultative endophytic bacterium have the ability to colonize the interior and surface of the roots as a function of the chemotaxis of rhizosphere exudates (Ahemad \& Kibret, 2014). They can convert atmospheric N to ammonium, produce phytohormones such as cytokinins, gibberilins and auxins (El-Hadi et al., 2009), increase water and mineral absorption, tolerance to abiotic stresses (Shameer \& Prasad, 2018; Fukami et al., 2018; Silva \& Pires, 2017), and are able to colonize the endorizosphere and xylem vessels (Fatma et al., 2008). Thus, there is a growing interest in inoculating microorganisms in vivo as they not only increase the productivity and phytochemical profile of medicinal plants but also reduce the use of chemical fertilizers (Adesemoye et al., 2009). 
Table 2. Review of medicinal plants species elicited by efficient microorganisms

\begin{tabular}{|c|c|c|c|c|c|c|}
\hline Scientific Name & Application via & Evaluation & Farmacogenesis & Effcient Treatment & Results & Articles \\
\hline $\begin{array}{l}\text { Foeniculum } \\
\text { vulgare Mill. }\end{array}$ & Soil & $\begin{array}{l}\text { Morphological features, } \\
\text { essential oil and } \\
\text { phenolic compounds }\end{array}$ & Fruits & $\begin{array}{l}\text { Azotobacter chroococcum, } \\
\text { Azospirillum lipoferum and } \\
\text { Bacillus megatherium }\end{array}$ & $\begin{array}{l}>\text { Plant height, } \mathrm{n}^{\circ} \text { of branches, } \\
\text { fresh and dry weight and weight } \\
\text { fresco and uselfulness of fruits } \\
>\text { Essential oil rates } \\
>\text { Anetol rates } \\
>\text { Absorption of } \mathrm{N} \text { and } \mathrm{P}\end{array}$ & $\begin{array}{l}\text { Mahfouz et al. } \\
(2007)\end{array}$ \\
\hline Majorana hortensis $\mathrm{L}$. & $\begin{array}{l}\text { Soil and } \\
\text { irrigation }\end{array}$ & Growth and essential oil & Leaf & Bacillus circulans & $\begin{array}{l}\text { *Azos. Brasiliense }+ \text { Azot. Chroococcum }+ \\
\text { B. polymyxa and B. circulans } \\
>\text { Plant-growth } \\
\text { * Azotobacter misturado + B. megaterium } \\
>\text { Essential oil rates } 39-52 \% \\
\text { * Nitrogen vines }+ \text { Bacillus circulans } \\
>\gamma \text {-terpinene rates }(16.83 \%) \text {, } \\
\text { a-terpinene }(13.11 \%), \\
\text { phellandrene }(2.41 \%), \text { a-mirrene }(2.01 \%)\end{array}$ & $\begin{array}{l}\text { Fatma et al. } \\
(2008)\end{array}$ \\
\hline Punica granatum $\mathrm{L}$. & $\begin{array}{l}\text { Soil and seed } \\
\text { inoculation }\end{array}$ & $\begin{array}{l}\text { Microbial activity, } \\
\text { chlorophyll and } \\
\text { nutrients rates }\end{array}$ & Seedlings & A. brasilense and G. mosseae & $\begin{array}{l}>\text { Leaf area and dry weight } \\
\text { a Rate total de chlorophill, accumulation } \\
\text { and reduction ofsugars } \\
>\text { Total phenols and amino nitrogen } \\
\text { > Dehydrogenase activity, alkaline } \\
\text { phosphotase and nitrogenase } \\
>\text { Microbial activity and nutrients rates }\end{array}$ & $\begin{array}{l}\text { Aseri et al. } \\
\text { (2008) }\end{array}$ \\
\hline Punica granatum $\mathrm{L}$. & $\begin{array}{l}\text { Soil and seed } \\
\text { inoculation }\end{array}$ & $\begin{array}{l}\text { Microbial activity, } \\
\text { chlorophyll and } \\
\text { nutrients rates }\end{array}$ & Seedlings & A. brasilense and G. mosseae & $\begin{array}{l}\text { > Leaf area and dry weight } \\
>\text { Rates total de chlorophill, } \\
\text { accumulation and reduction ofsugars } \\
>\text { Total phenols and amino nitrogen } \\
\text { > Dehydrogenase activity, alkaline } \\
\text { phosphotase and nitrogenase } \\
\text { > Microbial activity and nutrients rates }\end{array}$ & $\begin{array}{l}\text { Aseri et al. } \\
\text { (2008) }\end{array}$ \\
\hline $\begin{array}{l}\text { Mentha viridis } \mathrm{L} \text {. } \\
\text { Japanesemint: } \\
\text { Mentha arvensis } \mathrm{L} \text {. } \\
\text { Peppermint: } \\
\text { Mentha piperita } \mathrm{L} \text {. }\end{array}$ & Soil & $\begin{array}{l}\text { Essential oil usefullness } \\
\text { and chlorophyll }\end{array}$ & Dry leaves & Azospirillum + Azotobacter mixture & $\begin{array}{l}>\text { Height of Menta piperita } \mathrm{L} \text {., } \\
\text { biomass, dry weight, flower and root } \\
>\text { Essential oil usefullness Mentha arvensis } \\
\text { and Menta piperita } \mathrm{L} \text {. } \\
>\text { Microbial proliferation in the rizosphere } \\
\text { of the Menta Piperita } \\
>\text { Fungi rates-beneficial and harmful } \\
>\text { Chlorophill rates }\end{array}$ & $\begin{array}{l}\text { El-Hadi et al. } \\
\text { (2009) }\end{array}$ \\
\hline Pimpinella anisum $L$. & $\begin{array}{l}\text { Inoculation and } \mathrm{f} \\
\text { ertilization }\end{array}$ & $\begin{array}{l}\text { Seeds production and } \\
\text { essential oil rates }\end{array}$ & Seeds & $\begin{array}{l}10 \text { ton/ha }+ \text { inoculation of } \\
\text { Bacillus circulans with pulverization } \\
\text { in the stretching stem stage }\end{array}$ & $\begin{array}{l}>\text { Seed production of } 2973.2 \mathrm{~kg} / \mathrm{ha} \\
>\text { Essential oil rates }-104.3 \mathrm{~kg} / \mathrm{ha}\end{array}$ & $\begin{array}{l}\text { Mohammad } \\
\text { et al. (2012) }\end{array}$ \\
\hline $\begin{array}{l}\text { Matricaria } \\
\text { chamomilla } \mathrm{L} \text {. }\end{array}$ & Soil & Essential oil usefullness & Dry flowers & Azotobacter and Azospirillum & $>$ Essential oil usefullness & $\begin{array}{l}\text { Dastborhan } \\
\text { et al. (2012) }\end{array}$ \\
\hline Carum copticum $L$. & $\begin{array}{l}\text { Spray base of } \\
\text { the plant }\end{array}$ & Essential oil & Seed & Nitrogen fixers bacterium & $>$ Essential oil rates & $\begin{array}{l}\text { Ghilavizadeh } \\
\text { et al. (2013) }\end{array}$ \\
\hline Anethum graveolens $\mathrm{L}$. & $\begin{array}{l}\text { Soil and leaf } \\
\text { pulverization }\end{array}$ & $\begin{array}{l}\text { Nuber of umbels and } \\
\text { seeds production }\end{array}$ & Seed & $\begin{array}{l}\text { Micorrhiza gladus interadices } \\
\text { and Glomus mosseae }\end{array}$ & $\begin{array}{l}>\text { Production of umbel seeds } \\
>\text { Absorptionof water and nutrients }\end{array}$ & $\begin{array}{l}\text { Hashemzadeh } \\
\text { et al. (2013) }\end{array}$ \\
\hline Coriandrum sativum $\mathrm{L}$. & $\begin{array}{l}\text { Spray base of } \\
\text { the plant }\end{array}$ & $\begin{array}{l}\text { Growth and seeds } \\
\text { production }\end{array}$ & Seed & Nitrogen fixers bacterium & $>$ Umbel numbers, seed numbers & $\begin{array}{l}\text { Akhani et al. } \\
(2012)\end{array}$ \\
\hline Coriandrum sativum $\mathrm{L}$. & inoculation & $\begin{array}{l}\text { Essential oil rates } \\
\text { and components }\end{array}$ & Seed & $\begin{array}{l}\text { Biofertilizers (Inoculate seeds } \\
\text { with azotobacter + Azospirillum }\end{array}$ & $\begin{array}{l}>\text { Essential oil usefullness } \\
>\text { Rates of alpha-pinene }\end{array}$ & Darzi et al. \\
\hline Anethum graveolens $\mathrm{L}$. & Seed inoculation & Essential oil & Seeds & $\begin{array}{l}10 \text { ton of compound }+ \\
\text { inoculation of seeds }\end{array}$ & $\begin{array}{l}>\text { Seed production } \\
>\text { Essential oil usefullness }\end{array}$ & $\begin{array}{l}\text { Shahmohammad } \\
\text { et al. (2014) }\end{array}$ \\
\hline Medicago polymorpha $L$. & Seed inoculation & $\begin{array}{l}\text { Nutrients rates } \\
\text { and growth }\end{array}$ & Whole plant & $\begin{array}{l}\text { Vermicompound }+ \\
\text { arbuscularmicorrhiza }\end{array}$ & $\begin{array}{l}>\text { Rates of } \mathrm{N} \text { and } \mathrm{K} \text { in vegetal tissues } \\
>\text { Leaf area }\end{array}$ & $\begin{array}{l}\text { Akhazari et al. } \\
\text { (2015) }\end{array}$ \\
\hline $\begin{array}{l}\text { Chamomilla } \\
\text { recutita } \mathrm{L} \text {. Rausch. }\end{array}$ & $\begin{array}{l}\text { Leaf } \\
\text { pulverization }\end{array}$ & $\begin{array}{l}\text { Growth,essential oil } \\
\text { and flavonoids rates }\end{array}$ & Flower and fruit & - & Not statistically meaningful & $\begin{array}{l}\text { Kwiatkowski } \\
(2015)\end{array}$ \\
\hline Mentha arvensis $\mathrm{L}$. & Soil & $\begin{array}{l}\text { Essential oil, biomass } \\
\text { of leaf and roots, nutrients }\end{array}$ & Fresh leaf & G. fascicula-tum + E. oxido tolerans & $\begin{array}{l}>\text { Fresh weight and the plant stem proportion } \\
\text { of plants in saline or non saline conditions } \\
>\text { Essential oil usefulness } \\
<\text { Micorrhizae colonization (H. desiderata) } \\
>\text { Micorrhizae colonization (species of Glomus) } \\
\text { > Rates of P and N }\end{array}$ & $\begin{array}{l}\text { Bharti et al. } \\
\text { (2016) }\end{array}$ \\
\hline Mentha arvensis $\mathrm{L}$. & Soil & $\begin{array}{l}\text { Essential oil, biomass } \\
\text { of leaf and roots, nutrients }\end{array}$ & Fresh leaf & G. fascicula-tum + E. oxido tolerans & $\begin{array}{l}>\text { Fresh weight and the plant stem proportion } \\
\text { of plants in saline or non saline conditions } \\
>\text { Essential oil usefullness } \\
<\text { Micorrhizae colonization (H. desiderata) } \\
>\text { Micorrhizae colonization (species of Glomus) } \\
>\text { Rates of P and N }\end{array}$ & $\begin{array}{l}\text { Bharti et al. } \\
\text { (2016) }\end{array}$ \\
\hline Ocimum basilicum $\mathrm{L}$. & $\begin{array}{l}\text { Soil and seed } \\
\text { inoculation }\end{array}$ & $\begin{array}{l}\text { Growth, development } \\
\text { and essential oil }\end{array}$ & Leaf & $\begin{array}{l}\text { Bacillus sp. and } \\
\text { Pseudomonas sp. Bacterium s }\end{array}$ & $\begin{array}{l}>\text { Leaf areaárea foliar, } \mathrm{n}^{\circ} \text { of branches and dry weight } \\
>\text { Growth, usefullness and density of the roots } \\
>\text { Essential oil usefullness }\end{array}$ & $\begin{array}{l}\text { Tahami et al. } \\
\text { (2017) }\end{array}$ \\
\hline Rauwolfia serpentine & Soil and coal & $\begin{array}{l}\text { Growth, alkaloid rates, } \\
\text { microbial biomass }\end{array}$ & Dry roots & $\begin{array}{l}\text { Azotobacter chroococcum, } \\
\text { Azospirillum brasilense and } \\
\text { Pseudomnas putida }\end{array}$ & $\begin{array}{l}>\text { Growth } \\
>\text { Uselfullness and alkaloid rates } \\
>\text { Absorption of nitrite, nitrate and phosphate } \\
>\text { Usefullness of alkaloids }\end{array}$ & Rai et al. \\
\hline
\end{tabular}


The number of umbels and seeds increased with the application of Azotobacter chroococcum and Azospirillum lipoferum in plants of Coriandrum sativum L. (Akhani et al., 2012), which has fungicidal, bactericidal and anthelmintic properties (Shahmohammadi et al., 2014). As for Anethum graveolens (L.) seed production increased as well as the yield of essential oil. This may be related to the better development of the ontogenic phase of the species, as well as a higher uptake of nitrite, nitrate and phosphate (Cappellari et al., 2013), influencing on growth, increased leaf area, higher photosynthetic rates that may contribute to yield, essential oil production and increased concentration of active principles (Damam et al., 2016; Rai et al., 2017).

Several studies point out the importance and interest of applying Azotobacter spp. and Azospirillum spp. in vivo in order to improve the physiology and phytochemistry of medicinal plants. They can increase yield and content of active constituents of the essential oil in various medicinal species like Foeniculum vulgare Mill. (Mahfouz et al., 2007). Rauwolfia serpentina had better performance and anetol rates; higher alkaloids rates were found in Carum copticum. Rai et al. (2017); alpha-pinene content increased in Coriandrum sativum L. (Ghilavizadeh et al., 2013); on the cultivation of, had increased the alpha-pinene rates (Akhani et al., 2012); greater content of the essential oil of the Matricaria chamomilla L. (Dastborhan et al., 2012). When the Bacilus spp. is applied in the production, it's verified the increase on the radicular system and better usefulness of the essential oil (Tahami et al., 2017).

In addition to the rhizobacterium applied as elicitors, arbuscular mycorrhizal fungi (AM) can help to improve the physical, chemical and structural properties of the soil. By increasing the availability of phosphorus through its specialized hyphae, the organic matter content and reduction of the apparent soil density (Yousefi et al., 2011; Akhazari et al., 2015), water retention by stimulating the plant's root system to exploit greater soil volume and to assist in the accumulation of secondary metabolites (Swamy et al., 2016).

Among the species evaluated by Bharti et al. (2016) and Hashemzadeh et al. (2013) the AM fungi Gladus spp. and Glomus spp. can interfere in the physiological development, increasing the total content of chlorophyll, the accumulation of higher levels of nutrients, total phenols and amino nitrogen by increasing the activities of dehydrogenase, alkaline phosphatase and nitrogenase that causes alteration in the mineralization of nutrients present in organic matter (Aseri et al., 2008).

Studies have shown that application of fungi (AM) in the production of Mentha arvensis L. in saline and non-saline conditions may induce tolerance and/or resistance to abiotic stress like water and salt stress (Bharti et al., 2016). Therefore, agronomic characteristics can be improved, such as biomass, height, stem and leaf ratio, higher nitrogen and phosphorus absorption due to the increase of mycorrhizal colonization.

On the other hand, species of fungi (AM) under abiotic stress conditions such as Halomonas spp. reduced rhizosphere colonization and yield in essential oil content (Bharti et al., 2016). Similar results were found with the application of photosynthetic bacterium, actinobacterium, lactic acid bacterium, fermentation fungi and yeast in the cultivation of Chamomilla recutita L. Rausch. The authors did not find significant differences for essential oil yield and flavonoid content (Kwiatkowski et al., 2015).

Thus, the application of fungi and bacterium as elicitors in the in vivo cultivation of medicinal plants is an important tool in organic and agroecological production, which contributes to the production of raw material with quality and pharmacological interest. They can also improve the performance and optimization of the use of nutrients, opposing the application of chemicals in the production of medicinal plants, conferring quality production with respect to the man and to the environment (Adesemoye et al., 2009; Olivares et al., 2017).

\section{Final Considerations}

Based ont the reviewed studies, the use of eliciting agents in the cultivation of medicinal plants through the application of humic substances (fulvic and humic acid), efficient microorganisms in vivo, it opens opportunities for the development of organic fertilizers and biofertilizers that can be applied in organic and agroecological cultivation for a sustainable agriculture. The use of humic substances and microorganisms improved the physicochemical characteristics of the soil, increased availability of nutrients for medicinal species, contributed to growth and development through the production of phytohormones, induction of the root system, release of exudates, influence on phytochemistry, primary and secondary metabolism by increasing the production of active principles and essential oil for therapeutic, biological and pharmacological use in the treatment of numerous diseases. The use of these elicitor agents in the field, focusing on medicinal species, is a scientific and social potential in improving the yield and quality of the production of medicinal plants without contamination by pesticides and chemical fertilizers that, besides the social and environmental benefits, potentiate the production of metabolites plants. 


\section{References}

Adesemoye, A. O., Torbert, H. A., \& Kloepper, J. W. (2009). Plant growth-promoting rhizobacterium allow reduced application rates of chemical fertilizers. Microbial Ecology, 58, 921-929. https://doi.org/10.1007/s00248- 009-9531-y

Ahemad, M., \& Kibret, M. (2014). Mechanisms and applications of plant growth promoting rhizobacterium :Current perspective. Journal of King Saud University-Science, 26, 1-20. https://doi.org/10.1016/j.jksus.2013.05.001

Ahmed, Y. M., Shalaby, E. A., \& Shanan, N. T. (2013). The use of organic and inorganic cultures in improving vegetative growth, yield characters and antioxidant activity of roselle plants (Hibiscus sabdariffa L.). African Journal of Biotechnology, 10, 1988-1996. https://doi.org 10.5897/AJB10.876

Akahami, A., Darzi, M. T., \& Hadi, M. H. S. (2012). Effects of Biofertilizer and Plant Density on Yield Components and Seed Yield of Coriander (Coriandrum sativum). International Journal of Agricultureand Crop Sciences, 4, 1205-1211.

Akhzari, D., Attaeian, B., Arami, A., Mahmoodi, F., \& Aslani, F. (2015). Effects of Vermicompost and Arbuscular Mycorrhizal Fungi on Soil Properties and Growth of Medicago polymorpha L. Compost Science and Utilization, 23, 142-53. https://doi.org/10.1080/1065657X.2015.1013585

Aminifard, M. H., Aroiee, H., Azizi, M., Nemati, H., \& Jaafar, H. Z. E. (2012). Effect of humic acid on antioxidant activities and fruit quality of hot pepper (Capsicum annuum L.). Journal of Herbs, Spices andMedicinal Plants, 18, 360-369. https://doi.org/10.1080/10496475.2012.713905

Andrade, F. M. C. (2001). Effect of homeopathy on growth and yield of coumarin in "chambá" (Justicia pectoralis Jacq.). Revista Brasileira de Plantas Medicinais, 4, 19-28.

Andrade, F. M. C. E. C., \& Casali, V. W. D. C. (2011). Homeopathy, agroecology and sustainability. Revista Brasileirade Agroecologia, 6, 49-56.

Aseri, G. K., Neelam, J., Jitendra, P., Rao, A. V., \& Meghwal, R. (2008). Biofertilizers Improve Plant Growth, Fruit Yield, Nutrition, Metabolism and Rhizosphere Enzyme Activities of Pomegranate (Punica granatum L.) in Indian Thar Desert. Scientia Horticulturae, 117, 130-35. https://doi.org/10.1016/j.scienta.2008.03.014

Asli, S., \& Neumann, P. M. (2010). Rhizosphere humic acid interacts with root cell walls to reduce hydraulic conductivity and plant development. Plant and Soil, 336, 313-322. https://doi.org/10.1007/s11104-0100483-2

Ateia, M., Ran, J., Fujii, M., \& Yoshimura, C. (2017). The relationship between molecular composition and fluorescence properties of humic substances. International Journal of Environmental Science and Technology, 14, 867-880. https://doi.org/ 10.1007/s13762-016-1214-x

Bakker, P. A. H. M., Berendsen, R. L., Doornbos, R. F., Wintermans, P. C. A., \& Pieterse, C. M. J. (2013). The rhizosphere revisited: Root microbiomics. Frontiers in Plant Science, 4, 165. https://doi.org/10.3389/ fpls.2013.00165

Baldotto, M. A., \& Baldotto, L. E. B. (2014). Humic acids. Rev. Ceres, 61, 856-881. https://doi.org/10.1590/0034$737 \times 201461000011$

Baldotto, M. A., \& Baldotto, L. E. B. (2015). Organic carbon stocks and fractions and soil fertility under forest, agriculture and livestock. Revista Ceres, 62, 301-309. https://doi.org/10.1590/0034-737X201562030010

Balsan, R. (2006). Decurrent impacts of the agricultura modernization in Brazil, Campo-Território. Revista de Geografia Agrária, 1, 123-151.

Banchio, E., Bogino, P. C., Zygadlo, J., \& Giordano, W. (2008). Plant growth promoting rhizobacterium improve growth and essential oil yield in Origanum majorana L. Biochemical Systematics and Ecology, 36, 766-771. https://doi.org/10.1016/j.bse.2008.08.006

Bharti, N., Baghel, S., Barnawal, D., Yadav, A., \& Kalra, A. (2013). The greater effectiveness of Glomusmosseae and Glomus intraradices in improving productivity, oil content and tolerance of salt-stressed menthol mint (Mentha arvensis). Sci. of Food \& Agri., 93, 2154-2161. https://doi.org/10.1002/jsfa.6021

Bharti, N., Barnawal, D., Shukla, S., Tewari, S. K., Katiyar, R. S., \& Kalra, A. (2016). Integrated application of Exiguobacterium oxidotolerans, Glomus fasciculatum, and vermicompost improves growth, yield and quality 
of Mentha arvensis in salt-stressed soils. Industrial Crops and Products, 83, 717-728. https://doi.org/ 10.1016/j.indcrop.2015.12.021

Bhattacaryya, P., \& Jha, D. (2012). Plant growth-promoting rhizobacterium (PGPR): Emergence in agriculture. World J. Microbiol. Biotechnol, 28, 1327-1350. https://doi.org/ 10.1007/s11274-011-0979-9

BRASIL. (2011). Brazilian homeopathic pharmacopoeia (3rd ed.). Anvisa.

Bulgarelli, D., Schlaeppi, K., Spaepen, S., Van Themaat, E. V. L., \& Schulze-Lefert, P. (2013). Structure and functions of the bacterium 1 microbiota of plants. Annual Review of Plant Biology, 64, 807-838. https://doi.org/ 10.1146/annurev-arplant-050312-120106

Calixto, B, C. J., \& Siqueira, J. M. S. (2008). Drug Development in Brazil: Challenges. Gazeta Médica da Bahia, 78, 98-106.

Calvo, P., Nelson, L., \& Kloepper, J. W. (2014). Agricultural uses of plant biostimulants. Plant and Soil, 383, 3-41. https://doi.org/10.1007/s11104-014-2131-8

Canellas, L. P. (2008). Bioactivity and chemical characteristics of humic acids from tropical soils sequence. Soil Science, 173, 624-637. https://doi.org/10.1097/SS.0b013e3181847ebf

Canellas, L. P., \& Olivares, F. L. (2014). Physiological responses to humic substances as plant growth promoter. Chemical and Biological Technologies in Agriculture, 1, 1. https://doi.org/10.1186/2196-5641-1-3

Canellas, L. P., Olivares, F. L., Aguiar, N. O., Jones, D. L., Nebbioso, A., Mazzei, P., \& Piccolo, A. (2015). Humic and fulvic acids as biostimulants in horticulture. Scientia Horticulturae, 196, 15-27. https://doi.org/10.1016/ j.scienta.2015.09.013

Cappellari, L. R., Santoro, M. V., Nievas, F., Giordano, W., \& Banchio, E. (2013). Increase of secondarymetabolite content in marigold by inoculation with plant growth-promoting rhizobacterium . Applied Soil Ecology, 70, 16-22. https://doi.org/10.1016/j.apsoil.2013.04.001

Caron, V., Pereira, J., \& Camargo, P. (2015). Soil Conditioners: Humic And Fulvic Acids. Produtor Rural, $58,46$.

Çetin, E. S., \& Baydar, N. G. (2016). Elicitor applications to cell suspension culture for production of phenolic compounds in grapevine. Tarim Bilimleri Dergisi, 22, 42-53. https://doi.org/10.1501/Tarimbil_0000001366

Chagas, F. O., Pessotti, R. D. C., Caraballo-Rodríguez, A. M., \& Pupo, M. T. (2018). Chemical signaling involved in plant-microbe interactions. Chemical Society Reviews, 47, 1652-1704. https://doi.org/10.1039/ C7CS00343A

Chavarria, D. N. (2018). Response of soil microbial communities to agroecological versus conventional systems of extensive agriculture. Agriculture, Ecosystems and Environment, 264, 1-8. https://doi.org/10.1016/j.agee. 2018.05.008

Costa, T., \& Jorge, N. (2011). Chemical composition of nuts and edible seeds and their relation to nutrition and healthBioactive Compounds Present in Nuts and Walnuts. Ciência Biológica e Da Saúde, 13, 195-203.

Costa, V. C. O. (2008). Chemical composition and modulation of bacterium 1 drug resistance of the essential oil from the leaves of Rollinia leptopetala R.E. Fries. Revista Brasileira de Farmacognosia, 18, $245-248$. https://doi.org/10.1590/S0102-695X2008000200019

Craigie, J. S. (2011). Seaweed extract stimuli in plant science and agriculture. Journal of Applied Phycology, 23, 371-393. https://doi.org/ 10.1007/s10811-010-9560-4

Czelusniak, K. E., Brocco, A., Pereira, D. F., \& Freitas, G. B. L. (2012). Morpho-anatomy, phytochemistry and pharmacology of Mikania glomerata Sprengel: A brief literature reviewMikania glomerata Sprengel e Mikania laevigata Schulyz Bip. ex Baker. Revista Brasileira de Plantas Medicinais, 14, 400-409. https://doi.org/10.1590/S1516-05722012000200022

Damam, M., Kaloori, K., Gaddam, B., \& Kausar, R. (2016). Plant growth promoting substances (phytohormones) produced by rhizobacterium 1 strains isolated from the rhizosphere of medicinal plants. International Journal of Pharmaceutical Sciences Review and Research, 37, 130-136.

Darzi, M. T. A. A., \& Hadi, M. H. S. (2012). Influence of organic manure and bacterium of bacillus circulans on yield and essential oil concentration in anise (Pimpinella anisum). Internacional Journal of Agriculture and Crop Sciences, 4, 64-69. https://doi.org/10.5897/JMPR11.949 
Darzi, M. T., Shirkhodaei, M., \& Hadi, M. H. S. (2013). Effects of Vermicomost and Azotobacter and Azospirillum bacterium on quantity and quality of essential oil of coriander (Coriandrum sativum L.). International Journal of Farming and Allied Sciences, 2, 1277-1283. https://doi.org/2013-2-S/1277-1283

Dastborhan, S., Zehtab-Salmasi, S., Nasrollahzadeh, S., \& Tavassoli, A. R. (2012). Effect of Plant Growth-Promoting Rhizobacterium and Nitrogen Fertilizer on Yield and Essential Oil of German Chamomile (Matricaria chamomilla L.). Acta Horticulturae, 964, 121-28. https://doi.org/10.17660/ActaHortic.2012.964.15

Döbereiner, J. (1991). The Genus Azospirillum and Herbaspirillum. In A. Balows, H. G. Tripper, M. Dworkin, W. Harder, \& K.-H. Scleider (Eds.), The prokaryotes (2nd ed., pp. 2236-2253). New York: Springer-Verlag.

Dojima, T., \& Craker, L. E. (2016). Potential benefits of soil microorganisms on medicinal and aromatic plants. ACS Symposium Series, 12, 18. https://doi.org/10.1021/bk-2016-1218.ch006

Drosos, M., Nebbioso, A., Mazzei, P., Vinci, G., Spaccini, R., \& Piccolo, A. (2017). A molecular zoom into soil Humeome by a direct sequential chemical fractionation of soil. Science of the Total Environment, 586, 807-816. https://doi.org/10.1016/j.scitotenv.2017.02.059

Du. (2013). Effects of microbial elicitor on production of hypocrellin by Shiraia bambusicola. Folia Microbiologica, 58, 283-289. https://doi.org/ 10.1007/s12223-012-0203-9

Ebeling, A. G., Helena, L., Pereira, M. G., Flavia, E., Pinheiro, M., \& Valladares, G. S. (2011). Humic substances and relationship to soil attributes. Bragantia, 70, 157-165. https://doi.org/10.1590/S0006-87052011000 100022

El-Gohary, A. E., El-Sherbeny, S. E., Ghazal, G. M. E. M., Khalid, K. A., \& Hussein, M. S. (2014). Evaluation of Essential Oil and Monoterpenes of Peppermint (Mentha piperita L.) under Humic Acid with Foliar Nutrition. Journal of Materials and Environmental Science, 5, 1885-1890.

Etesami, H., \& Maheshwari, D. K. (2018). Use of plant growth promoting rhizobacterium (PGPRs) with multiple plant growth promoting traits in stress agriculture: Action mechanisms and future prospects. Ecotoxicology and Environmental Safety, 156, 225-246. https://doi.org/10.1016/j.ecoenv.2018.03.013

Fatma, A. G., Lobna, A. M., \& Osman, N. M. (2008). The effects of compost and biofertilizers on the growth, yield and essential Oil of sweet marjoram (Majorana hortensis) plant. Int. J. Agric. Biol., 10, 381-387.

Fishcer, T. (2017). Humic supramolecular structures have polar surfaces and unpolar cores in native soil. Chemosphere, 183, 437-443. https://doi.org/10.1016/j.chemosphere.2017.05.125

Fukami, J., Cerezini, P., \& Hungria, M. (2018). Azospirillum: Benefits that go far beyond biological nitrogen fixation. AMB Express, 8, 73. https://doi.org/ 10.1186/ s13568-018-0608-1

Gharib, F. A., Moussa, L. A., \& Massoud, O. N. (2008). Effect of compost and bio-fertilizers on growth, yield and $\mathrm{n}$ essential oil of sweet marjoram (Majorana hortensis) plant. International Journal of Agriculture and Biology, 10, 381-387.

Ghasemi, K. (2015). Antioxidant properties of garlic as affected by selenium and humic acid treatments. New Zealand Journal of Crop and Horticultural Science, 43, 173-181. https://doi.org/10.1080/01140671. 2014.991743

Ghilavizadeh, A., Darzi, M. T., Haj, M., \& Hadi, S. (2013). Effects of Biofertilizer and Plant Density on Essntial Oil Content and Yield Traits of Ajowan (Carum copticum). Middle-East J. Sci. Res., 14, 1508-1512. https://doi.org/10.5829/idosi.mejsr.2013.14.11.2364

Gobbo-Neto, L., \& Lopes, N. P. (2007). Medicinal Plants: Factors of influence on the contente of secondary metabolites. Quimica Nova, 30, 374-381. https://doi.org/10.1590/S0100-40422007000200026

Gupta, S., Kaushal, R., \& Sood, G. (2018). Impact of Plant Growth-Promoting Rhizobacterium on Vegetable Crop Production. International Journal of Vegetable Science, 24, 289-300. https://doi.org/10.1080/19315260. 2017.1407984

Halpern, M., Bar-Tal, A., Ofek, M., Minz, D., Muller, T., \& Yermiyahu, U. (2015). The Use of Biostimulants for Enhancing Nutrient Uptake. Advances in Agronomy, 130, 141-174. https://doi.org/10.1016/bs.agron.2014. 10.001 
Hashemzadeh, F., Mirshekari, B., Khoei, F. R., Yarnia, M., \& Tarinajad, A. (2013). Effect of bio and chemical fertilizers on seed yield and its components of dill (Anethum graveolens). Journal of Medicinal Plants Research, 7, 111-117. https://doi.org/ 10.5897/JMPR12.363

Hendawy, S. F., Hussein, M. S., El-Gohary, A. E., \& Ibrahim, M. E. (2015). Effect of Foliar Organic Fertilization on the Growth, Yield and Oil Content of Mentha Piperita Var. Citrata. Asian Journal of Agricultural Research, 9, 237-248. https://doi.org/10.3923/ajar.2015.237.248

Karami, A., \& Shamsuddin, Z. H. (2013). Phytoremediation of heavy metals with several efficiency enhancer methods. African Journal of Biotechnology, 9, 3689-3698.

Kawahigashi, M., Sumida, H., \& Yamamoto, K. (2005). Size and shape of soil humic acids estimated by viscosity and molecular weight. Journal of Colloid and Interface Science, 284, 463-469. https://doi.org/10.1016/j.jcis. 2004.10 .023

Khazaie, H. R., Rezaie, E. E., \& Bannayan, M. (2011). Application times and concentration of humic acid impact on aboveground biomass and oil production of hyssop (Hyssopus officinalis). Journal of Medicinal Plants Research, 5, 5148-5154.

Kołodziej, B., Sugier, D., \& Bielińska, E. (2013). The effect of leonardite application and various plantation modalities on yielding and quality of roseroot (Rhodiola rosea L.) and soil enzymatic activity. Journal of Geochemical Exploration, 129, 64-69. https://doi.org/10.1016/j.gexplo.2012.10.014

Kwiatkowska-Malina, J. (2018). Functions of organic matter in polluted soils: The effect of organic amendments on phytoavailability of heavy metals. Applied Soil Ecology, 123, 542-545. https://doi.org/10.1016/j.apsoil. 2017.06.021

Kwiatkowski, C. A. (2015). Yield and Quality of Chamomile (Chamomilla recutita (L.) Rausch.) Raw Material Depending on Selected Foliar Sprays and Plant Spacing. Acta Scientiarum Polonorum. Hortorum Cultus, 14, 143-156.

Lazzari, F. M., \& Souza, A. S. (2017). Green Revolution: Impacts on Traditional Knowledge (pp. 1-16). $4^{\circ}$ Congresso Internacional de Direito e Contemporaneidade.

Lee, Y. P., Fujii, M., Kikuchi, T., Terao, K., \& Yoshimura, C. (2017). Variation of iron redox kinetics and its relation with molecular composition of standard humic substances at circumneutral $\mathrm{pH}$. PLoS ONE, 12, 4 . https://doi.org/10.1371/journal.pone.0176484

Lehmann, K. (2018). Selective transport and retention of organic matter and bacterium shapes initial pedogenesis in artificial soil-A two-layer column study. Geoderma, 325, 37-48. https://doi.org/10.1016/j.geoderma. 2018.03.016

Leite, P. A. K. (2016). Selection of rhizobacterium as growth promoters in watermelon. Scientia Plena, 12, 4.

Licá, I. C. L., Soares, A. M. D. S., de Mesquita, L. S. S., \& Malik, S. (2018). Biological properties and pharmacological potential of plant exudates. Food Research International, 105, 1039-1053. https://doi.org/ 10.1016/j.foodres.2017.11.051

Luciano, P. C., \& Fabio, L. O. (2017). Production of border cells and colonization of maize root tips by Herbaspirillum seropedicae are modulated by humic acid. Plant and Soil, 417, 403-413. https://doi.org/ 10.1007/s11104-017-3267-0

Mahfouz, S. A., \& Shamf-Eldin, M. A. (2007). Effect of Mineral vs. Biofertilizer on Growth, Yield, and Essential Oil Content of Fennel (Foeniculum vulgare Mill.). International Agrophysics, 21, 361-66. https://doi.org/ $10.1055 / \mathrm{s}-2007-987419$

Matos, A. K. V. de. (2010). Green Revolution, Biotechnology and Alternative Technologies. Cadernos da FUCAMP, 10, 01-17.

Matos, P. F., \& Pessoa, V. L. S. (2011). The Modernization of Agriculture in Brazil and the New Uses of the Territory. Geo UERJ, 2, 290-322. https://doi.org/ 10.12957/geouerj.2011.2456

Miranda, H. (2008.) The environmental issue at the origin of the Brazilian agrarian problem and the case of the South region 1. Economia, 2, 103-132.

Mohammad, T. D. (2012). Effects of the application of organic manure and biofertilizer on the fruit yield and yield components in Dill (Anethum graveolens). Journal of Medicinal Plants Research, 6, 17. https://doi.org/ 10.5897/JMPR12.204 
Mohammadi, H. (2017). Effects of beneficial root pseudomonas on morphological, physiological, and phytochemical characteristics of Satureja hortensis (Lamiaceae) under water stress. Revista Brasileira de Botanica, 40, 41-48. https://doi.org/10.1007/s40415-016-0319-2

Muscolo, A., Sidari, M., \& Nardi, S. (2013). Humic substance: Relationship between structure and activity. deeper information suggests univocal findings. Journal of Geochemical Exploration, 129, 57-63. https://doi.org/ 10.1016/j.gexplo.2012.10.012

Nadia, E. H., El-Ala, H. K. A., El-Azim, W. M. A. (2009). Response of some Mentha species to plant growth promoting bacterium (PGPB) isolated from soil rhizosphere. Australian Journal of Basic \& Applied Sciences, 3(4), 4437-4448.

Nardi, S., Ertani, A., \& Francioso, O. (2017). Soil-root cross-talking: The role of humic substances. Journal of Plant Nutrition and Soil Science, 180, 5-13. https://doi.org/10.1002/jpln.201600348

Nebbioso, A., \& Piccolo, A. (2012). Advances in humeomics: Enhanced structural identification of humic molecules after size fractionation of a soil humic acid. Analytica Chimica Acta, 720, 77-90. https://doi.org/10.1016/j.aca.2012.01.027

Olivares, F. L. (2017). Plant growth promoting bacterium and humic substances: Crop promotion and mechanisms of action. Chemical and Biological Technologies in Agriculture, 4, 1. https://doi.org/10.1186/s40538-017- 0112-x

Ozfidan-Konakci, C., Yildiztugay, E., Bahtiyar, M., \& Kucukoduk, M. (2018). The humic acid-induced changes in the water status, chlorophyll fluorescence and antioxidant defense systems of wheat leaveswith cadmium stress. Ecotoxicology and Environmental Safety, 155, 66-7. https://doi.org/10.1016/j.ecoenv.2018.02.071

Panya, M., Naresh Kumar, G., \& Rajkumar, S. (2013). Invasion of rhizobial infection thread by non-rhiobia for colonization of vigna radiata root nodules. FEMS Microbiology Letters, 348, 58-65. http//doi.org/ $10.1111 / 1574-6968.12245$

Pereira, L. A., \& Raimunda, A. D. S. (2016). The intensive use of pesticides-The new face of the agrarian question. Okara: Geografia em Debate, 10, 185-194.

Perira, R. J., \& Cardoso, M. D. G. (2012). Vegetable secondary metabolites and antioxidants benefits. Journal of Biotechnology and Biodiversity, 3, 46-152.

Rafiee, H. (2016). Application of plant biostimulants o new approach to improve the biological responses of medicinal plants - A critical review. Journal of Medicinal Plants, 15, 6-39.

Rai, A., Sanjeev, K., Kuldeep, B., Nandita, S., \& Rana, P. S. (2017). Improvement in growth and alkaloid content of Rauwolfia serpentina on application of organic matrix entrapped biofertilizers (Azotobacter chroococcum, Azospirillum brasilense and Pseudomonas putida). Journal of Plant Nutrition, 41, 1-11. https://doi.org/ 10.1080/01904167.2016.1222419

Ramachandra, R. A O., \& Ravishankar, G. A. (2002). Plant cell cultures: Chemical factories of secondary metabolites. Biotechnology Advances, 20, 101-153. https://doi.org/10.1016/S0734-9750(02)00007-1

Richardson, A. E., Barea, J.-M., Mcneill, A. M., \& Prigent-Combaret, C. (2009). Acquisition of phosphorus and nitrogen in the rhizosphere and plant growth promotion by microorganisms. Plant and Soil, 321, 305-339. https://doi.org/ 10.1007/s11104-009-9895-2

Said-Al Ahl, H., Gendy, A. G., \& El, E. A. O. (2016). Humic acid and indole acetic acid affect yield and essential oil of dill grown under two different locations in Egypt. International Journal of Pharmacy and Pharmaceutical Sciences, 8, 146-157.

Santi, C., Bogsz, D., \& Franche, C. (2013). Biological nitrogen fixation in non-legume plants. Annals of Botany, 111, 743-767. https://doi.org/10.1093/aob/mct048

Santos, D. Y. A. C. (2015). Applied Botany: Secondary metabolites in plant-environment interaction.

Shahabivand, S., Padash, A., Aghaee, A., Nasiri, Y., \& Rezaei, P. F. (2018). Plant biostimulants (Funneliformis mosseae and humic substances) rather than chemical fertilizer improved biochemical responses in peppermint. Iranian Journal of Plant Physiology, 8(2), 2333-2344. https://doi.org/10.22034/ijpp.2018. 539109

Shahmohammadi, F., \& Darzi, M. T. (2014). Influence of Compost and Biofertilizer on Yield and Essential Oil of Dill (Anethum graveolens L.). Int J Adv Biol Biom Res, 2, 446-55. 
Shameer, S., \& Prasad, T. N. V. K. V. (2018). Plant growth promoting rhizobacterium for sustainable agricultural practices with special reference to biotic and abiotic stresses. Plant Growth Regulation, 84(3), 603-615. https://doi.org/10.1007/s10725-017-0365-1

Silva Lima, L., Olivares, F. L., Rodrigues de Oliveira, R., Vega, M. R. G., Aguiar, N. O., \& Canellas, L. P. (2014). Root exudate profiling of maize seedlings inoculated with Herbaspirillum seropedicaeand humic acids. Chemical and Biological Technologies in Agriculture, 1, 23. https://doi.org/10.1186/s40538-014-0023-z

Silva, S. R., \& Pires, J. L. F. (2017). Response of 'BRS Guamirim' wheat to the application of Azospirillum, nitrogen and growth-promoting substances. Revista CiÊncia Agronômica, 48, 4. https://doi.org/10.5935/ 1806-6690.20170073

Swamy, M. K., Sayeed Akhtar, M., \& Sinniah, U. R. (2016). Response of PGPR and AM fungi toward growth and secondary metabolite production in medicinal and aromatic plants. Plant, Soil and Microbes, 2, 145-168. https://doi.org/10.1007/978-3-319-29573-2_7

Tahami, M. K., Jahan, M., Khalilzadeh, H., \& Mehdizadeh, M. (2017). Plant Growth Promoting Rhizobacterium in an Ecological Cropping System: A Study on Basil (Ocimum basilicum L.) Essential Oil Production. Industrial Crops and Products, 107, 97-104. https://doi.org/10.1016/j.indcrop.2017.05.020

Trevisan, S., Botton, A., Vaccaro, S., Vezzaro, A., Quaggiotti, S., \& Nardi, S. (2011). Humic substances affect Arabidopsis physiology by altering the expression of genes involved in primary metabolism, growth and development. Environmental and Experimental Botany, 74, 45-55. https://doi.org/10.1016/j.envexpbot. 2011.04.017

Trinh, C. S., Jeong, C. Y., Lee, W. J., Truong, H. A., Chung, N., Han, J., ... Lee, H. (2018). Paenibacillus pabuli strain P7S promotes plant growth and induces anthocyanin accumulation in Arabidopsis thaliana. Plant Physiology and Biochemistry, 129, 264-272. https://doi.org/10.1016/j.plaphy.2018.06.001

Vaccaro, S., Ertani, A., Nebbioso, A., Muscolo, A., Quaggiotti, S., Piccolo, A., \& Nardi, S. (2015). Humic substances stimulate maize nitrogen assimilation and amino acid metabolism at physiological and molecular level. Chemical and Biological Technologies in Agriculture, 2, 5. https://doi.org/10.1186/s40538-015-0033-5

Vafadar, F., Amooaghaie, R., \& Otroshy, M. (2014). Effects of plant-growth-promoting rhizobacterium and arbuscular mycorrhizal fungus on plant growth, stevioside, NPK, and chlorophyll content of Stevia rebaudiana. Journal of Plant Interactions, 9, 128-136. https://doi.org/10.1080/17429145.2013.779035

Yousefi, A. A., Khavazi, K., Moezi, A. A., Rejali, F., \& Nadian, H. A. (2011). Phosphate solubilizing bacterium and arbuscular mycorrhizal fungi impacts on inorganic phosphorus fractions and wheat growth. World Applied Sciences Journal, 9, 1310-1318.

Zhalnina, K. (2018). Dynamic root exudate chemistry and microbial substrate preferences drive patterns in rhizosphere microbial community assembly. Nature Microbiology, 1, 11. https://doi.org/10.1038/s41564018-0129-3

Zhao, Q., Wu, Y. N., Fan, Q., Han, Q. Q., Paré, P. W., Xu, R., ... Zhang, J. L. (2016). Improved Growth and Metabolite Accumulation in Codonopsis pilosula (Franch.) Nannf. by Inoculation of Bacillus amyloliquefaciens GB03. Journal of Agricultural and Food Chemistry, 64, 8103-8108. https://doi.org/10. 1021/acs.jafc.6b03390

Zheng, W., Zhao, Z., Gong, Q., Zhai, B., \& Li, Z. (2018). Responses of fungal-bacterium 1 community and network to organic inputs vary among different spatial habitats in soil. Soil Biology and Biochemistry, 125, 54-63. https://doi.org/10.1016/j.soilbio.2018.06.029

\section{Copyrights}

Copyright for this article is retained by the author(s), with first publication rights granted to the journal.

This is an open-access article distributed under the terms and conditions of the Creative Commons Attribution license (http://creativecommons.org/licenses/by/4.0/). 